\title{
Correction to: Trace elements exposure influences proximate body composition and antioxidant enzyme activities of the species tilapia and catfish in Burullus Lake-Egypt: human risk assessment for the consumers
}

\author{
Heba H. Abdel-Kader ${ }^{1} \cdot$ Mohamed H. Mourad $^{1}$ \\ Published online: 17 August 2020 \\ (C) Springer-Verlag GmbH Germany, part of Springer Nature 2020
}

Correction to: Environmental Science and Pollution Research https://doi.org/10.1007/s11356-020-10207-2

The correct images of figs. 2 and 3 are presented in this paper.

Publisher's note Springer Nature remains neutral with regard to jurisdictional claims in published maps and institutional affiliations.

Heba H. Abdel-Kader

hebaelalkamy3232@gmail.com

1 National Institute of Oceanography and Fisheries, NIOF,

Alexandria, Egypt 
Fig. 2 Proximate body composition in muscle tissue of tilapia species and C. gariepinus. Data are expressed as mean values and standard errors of the mean $(\mathrm{SEM})(\mathrm{n}=6)$. Different letters are significantly different $P$ $<0.05$ in the same graph
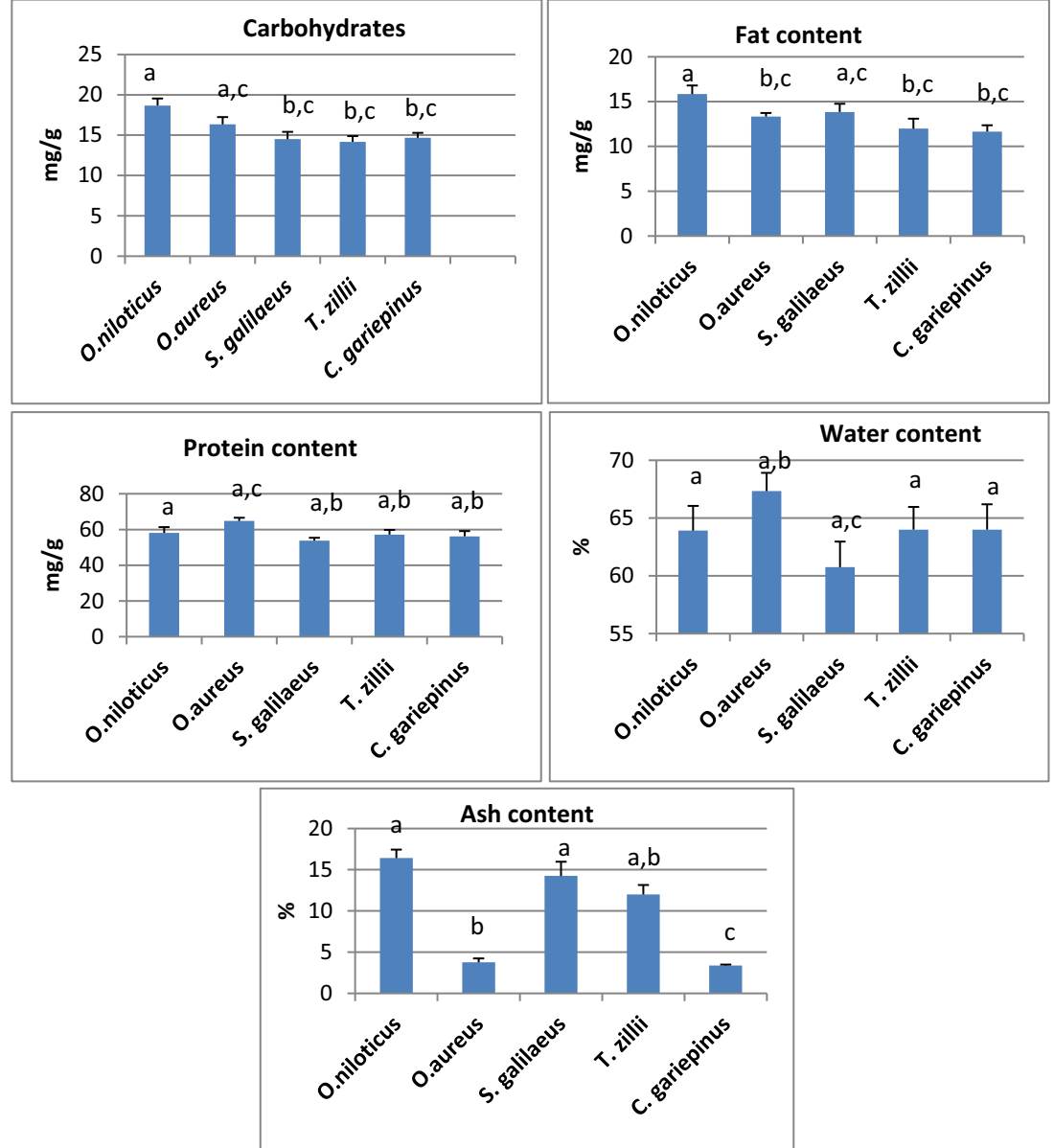
Fig. 3 Antioxidant enzyme activity in the liver tissue of tilapia species and $C$. gariepinus. Data are expressed as mean values and standard errors of the mean $(\mathrm{SEM})(\mathrm{n}=6)$. Different letters are significantly different $P<0.05$ in the same graph

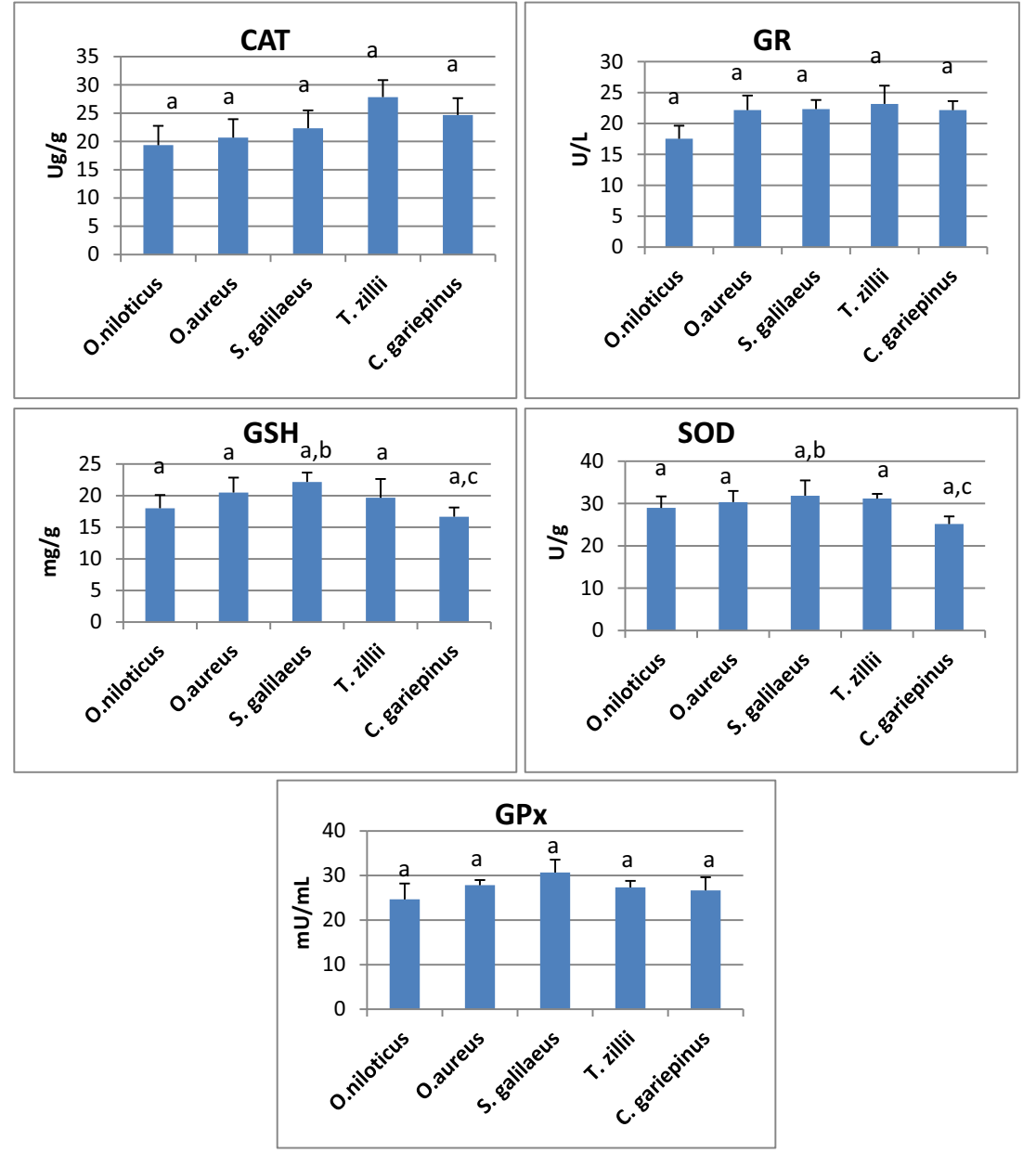

